\section{No. 4631 August 2, 1958}

niques and the performance and significance of crucial experiments. Among them may be noted the account of Becquerel's discovery of radioactivity in uranium, a model of the laboratory in Cambridge where Cockeroft and Walton first split the atom without the use of natural radioactivity, and a replica of the remarkably simple apparatus with which Hahn and Strassmann first recognized nuclear fission.

The remaining exhibits, those of the third type, which far outnumber the rest, are concerned with the methods and results of the latest research. They include a great deal of working apparatus-in the Atom section, for example, there are two working nuclear reactors-and many of them are concerned with quite advanced ideas. The general level of difficulty in fact approaches that of the exhibits at a Royal Society conversazione. It is searcely fair to single out any of these exhibits for special attention, but some account of the Russian exhibits may interest the many people who are unlikely ever to visit the U.S.S.R., and it will also serve to indicate the standard attained by the exhibits in general. They are characterized by large frameworks standing on illuminated bases of metal and glass and carrying diagrams and models in fluorescent paint and neon lights which illustrate the subject of the exhibit. These centre-pieces are designed to attract attention to the exhibits, the serious contents of which generally consist of the latest apparatus, usually in working order and operated by a resident staff of scientists and technicians, and accounts of the results obtained by its use. Thus in the Crystal section the Russian exhibit on crystal structure determination by means of X-ray and electron diffraction consists of an array of crystal structure models mounted on a characteristic centre-piece, alongside an elegant apparatus for electron diffraction studies of single crystals from the Crystallographic Institute of the Academy of Sciences in Moscow. In the Molecule section the exhibit on chain reactions by Prof. N. N. Semenov, who shared with Sir Cyril Hinshelwood the 1956 Nobel Prize for Chemistry, has for its central feature an elaborate panel in which the course of various reactions is illustrated by means of automatically controlled lights. This is surrounded by apparatus used in the study of such reactions, including a mass-spectrograph for the study of free radicals, a high-speed camera for the study of explosions and an apparatus for the study of reactions under high pressures.

The British contribution of more than fifty exhibits in all parts of the hall was organized by Sir Lawrence Bragg, at the Royal Institution, with the special co-operation of Prof. C. F. Powell and the United Kingdom Atomic Energy Authority in the Atom section, Prof. E. R. H. Jones in the Molecule section, and Prof. Alex. Haddow in the Living Cell section. The individual exhibits were arranged by scientists throughout the country with the help of many university and government laboratories and industrial organizations. Most of them were designed in general accordance with the standards recommended by Gunther Hoffstead.

The British exhibits in the Atom section include models of the Cockcroft-Walton laboratory, the 7-GeV. proton accelerator now being built at Harwell and the Harwell tandem generator. They also include a modern mass-spectrometer shown in comparison with a replica of the 1937 Aston mass-spectrograph from the Cavendish Laboratory, and an exhibit illustrating the discovery of mesons in cosmic rays. In the Crystal section they include accounts of the structures of collagen, deoxyribonucleic acid and vitamin $B_{12}$, determined by the methods of $\mathrm{X}$-ray crystallography, together with a description of the tertiary structure of the protein myoglobin, also determined very recently by these methods. Also included are exhibits on neutron diffraction investigations, the growth of crystals and the nature of crystal surfaces and dislocations as they are observed directly by electron microscopy. In the Molecule section they illustrate polar molecules, electron magnetic resonance, chromatography, insulin, vitamin $B_{12}$ again, reaction kineties, conformational analysis and radiochemistry. The British exhibits in the Living Cell section include accounts of proteins, cell division, 'lamp brush' chromosomes, the human chromosome number, the function of deoxyribonucleic acid, radiobiology, the structure of viruses, the malaria parasite, the mechanism of muscle contraction, the fine structure of Amoeba proteus and the effects of vitamin $A$ on cells grown in tissue culture. The film programmes shown daily in the small cinemas include a high proportion of British films on loan for the duration of the exhibition from a number of laboratories, film libraries and film makers.

The International Science Hall has now been open to the public rather more than two months and a large number of people have visited it. Many of them agree that although it is more than usually successful in presenting science at a popular level, it is most successful as a science exhibition for scientists. Visitors who have had no scientific training are often overawed by the scope and complexity of the exhibits, despite the many ingenious efforts that have been made to explain them. The people likely to profit most from visiting the Science Hall are undergraduate scientists and specialists, who will find there a review of the latest research in physics, chemistry and biology provided by leading authorities in each subject, and also a striking demonstration that science is best learned as a whole rather than divided into separate subjects that become increasingly less selfcontained as knowledge advances. The exhibition closes on October 19.
D. C. Phinlires

\title{
ANTARCTIC RESEARCH
}

T HE idea of holding an informal symposium on Antarctic research in New Zealand during February 1958, following the relief of Antarctic stations, was first discussed by the members of the United States and New Zealand National Committees for the International Geophysical Year. Conceived as a meeting between American and New Zealand field scientists, its scope was broadened at the 1957 Paris conference to include all nations with a working interest in the Antarctic. The confluence of several expeditions at Wellington was rather demanding in view of the exigencies of Antarctic operations but, through the goodwill of all and some sacrifice on the part of many, about seventy scientists from 
Australia, France, Great Britain, New Zealand, South Africa, the United States and the U.S.S.R. were able to attend the meetings held in Wellington during February 18-22.

The participants were welcomed to New Zealand by the Prime Minister (the Right Hon. Walter Nash, P.C.) at a morning reception. Mr. Nash expressed the hope that future Antarctic research would take place "in the spirit of the International Geophysical Year". Business meetings of two types were arranged : the general meeting, at which informal papers would be presented; and the discussion meeting, mainly confined to the round-table conference of specialists. A considerable number of visiting and New Zealand scientists attended the latter meetings to listen to the discussions. Each meeting was presided over by a worker in the subject, and because of the informal nature of the symposium no attempt will be made to present the full proceedings.

The first meeting, devoted to "Special Investigations in Glaciology", had as its chairman Dr. J. Zumberge (United States). So much material was available on this subject that a whole day was devoted to it. Dr. T. Pewe (United States) outlined his summer's work on the glaciological history of McMurdo Sound, mourning the fact that the terminal moraines, from which a good deal of the history can be read, lie on the sea-bottom. Apart from two late Pleistocene glacial advances, there is evidence of a much older and more extensive advance of the Antarctic ice cap into McMurdo Sound, which covered all the valleys in the area and filled the Sound itself with glacier ice. Questions concerning the synchronism of Antarctic glacial cycles with other regions will probably best be answered by carbon dating of the samples collected from the deltaic beds in the ponds of the Ferrar and Koettlitz Glaciers. Periglacial processes on Antarctic rocks between $50^{\circ}$ E. and $170^{\circ}$ E. were described by Prof. K. K. Maarkov (U.S.S.R.). The physical and chemical weathering processes are similar to areas such as the cold, highland deserts of Asia as well as northern and western Greenland, the dominant factors being long duration of solar radiation, low humidity and low temperatures. Solifluction is observed but is feeble. The techniques of obtaining ice cores, developed in Greenland, were applied to a borehole at Byrd Station, which reached a depth of $1,013 \mathrm{ft}$. The Failing 1500 rig was operated by three men and 98 per cent of core was recovered, a remarkable achievement. The bottom layer is of the order of 700 years old, there being an average annual accumulation of $20 \mathrm{~cm}$. water equivalent. E. W. Marsholl (United States), after describing these efforts, gave a detailed list of temperatures and densities. More primitive methods were used by R. Cameron (United States) at an inland base 50 miles from Wilkes Station, where a pit $2 \mathrm{~m}$. square was dug to a depth of $35 \mathrm{~m}$., an auger hole being drilled a further $27 \mathrm{~m}$. Stratigraphy, density and sastrugi patterns were investigated. At a depth of $33 \mathrm{~m}$. a tunnel $2 \mathrm{~m}$. in diameter and $6 \mathrm{~m}$. long was excavated to study deformation. The average annual accumulation was $15 \mathrm{~cm}$. water equivalent. A comprehensive account of the detailed Soviet studies on the movement, mass economy, heat balance, temperature regime, form and thickness, snow cover and alimentation of the Antarctic ice sheet was given by Prof. P. A. Shoumsky (U.S.S.R.). The east Antarctic ice sheet has a complex irregular form conditioned by sub-glacial relief ; on the whole, it probably approximates to a flattened ellipse with irregularities introduced by the topography of the bedrock.

Deformation of the Ross Ice Shelf produced by the presence of Roosevelt Island was the subject of a special study by a team led by Dr. J. Zumberge. An extensive grid was surveyed during the past summer, and by repeating the survey in the summer of 1958-59 it is hoped to measure the rate of strain in various directions. Use was also made of dial strain gauges to measure the change in width of crevasses. Ice structures resulting from compression, tension and shear are all present in the area. The Ross Ice Shelf is between 230 and $290 \mathrm{~m}$. thick around Little America, $300 \mathrm{~m}$. thick off Minna Bluff and $420 \mathrm{~m}$. thick near the Beardmore Glacier, being still afloat in the latter position, according to $\mathrm{H}$. Bennett (United States), a member of the Ross Ice Shelf traverse party which covered 1,440 miles over the Shelf during the past summer. Seismic shots every 30 miles were supplemented by gravity and magnetic observations and glaciological pit work. The thickness of the ice and the depth of the bottom of the Ross Sea were obtained by using the measured travel-time for reflexion from the sea bottom and assumed velocities for ice and water.

B. Imbert (France) was chairman at the second meeting, on "The Topography of the Sub-Glacial Continent". At this meeting the provisional results of all traverses except that of the United States party to the Weddell Sea were presented and techniques discussed, even though at the time of the symposium. some traverses were not quite completed (Fig. 1). Considerable geographical discoveries were made by the Byrd Station traverse party and during the support and reconnaissance flights. From the Ross Ice ShelfRockefeller Plateau boundary to the end of leg 1 $\left(76^{\circ} 30^{\prime} \mathrm{S} ., 113^{\circ} \mathrm{W}\right.$.) the ice-rock interface is rough, the thickness of the ice varying between 600 and $2,700 \mathrm{~m}$.; all but a few peaks of the rock floor are

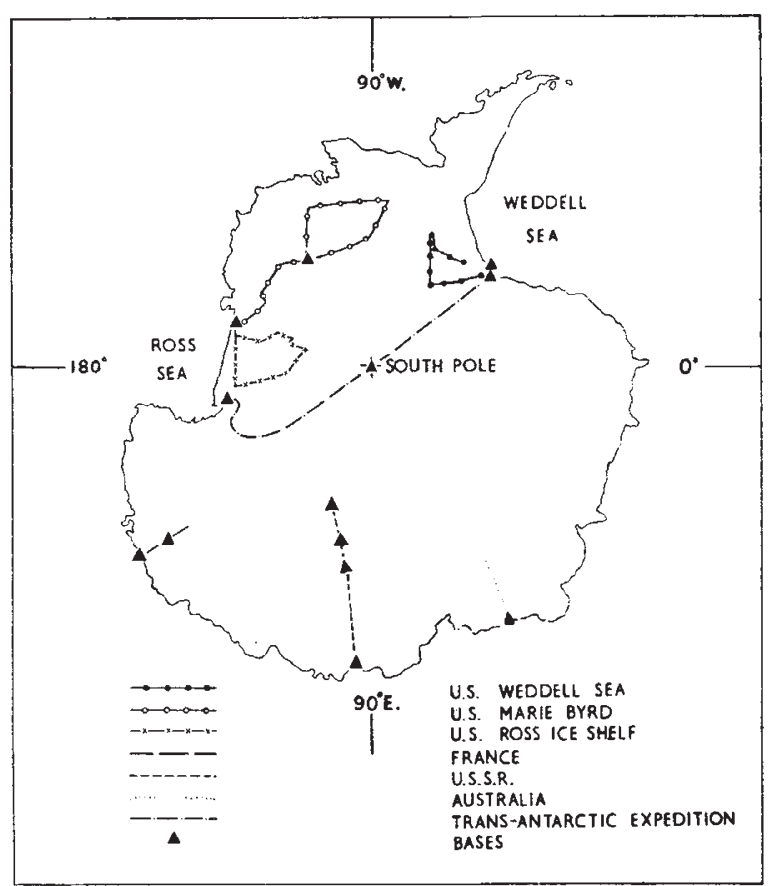

Fig. 1. Antarctica, showing major scientific traverse routes $(1957-58)$ 
at present below sea-level, the major portion far enough below to be under water if the ice were removed and the land allowed to rise into isostatic balance. Leg 2 shows quite a different picture, with a smooth bottom, great thickness of ice (from 2,300 to more than $3,500 \mathrm{~m}$.), and broad gravity anomalies. Near the middle of the leg the rock floor reaches a depth of $2,000 \mathrm{~m}$. below sea-level at a point where the elevation of the surface is a little more than $1,500 \mathrm{~m}$. Leg 3, south-west from the Sentinels ( $77^{\circ}$ $30^{\prime} \mathrm{S} ., 89^{\circ} \mathrm{W}$.) was in a still different type of area-. the rock floor being very rough and mostly above sea-level, breaking the ice surface in several places to form nunataks. This evidence indicates, subject to further examination of rock samples, that the Sentinels structure extends south-west at least as far as $80^{\circ} 30^{\prime} \mathrm{S} ., 98^{\circ} \mathrm{W}$.

The results of the Soviet, Australian and French radial profiles in East Antarctica showed some similarity, that is, complexity of land topography, mainly above sea-level except near the coast, but with great thicknesses of ice as high altitudes were reached. Dr. F. Jacka (Australia) noted the successful use by the Australians of a powered auger which enabled them to lay charges at depths of $30 \mathrm{~m}$. There was agreement among all speakers that a small charge detonated at as great a depth as possible contributed greatly to good seismic records. G. Pratt, seismologist with the Trans-Antarctic Expedition, forwarded his preliminary results from Southice to Midway depot $\left(81^{\circ} 30^{\prime}\right.$ S., $146^{\circ} 09^{\prime}$ E. $)$. On the Weddell Sea side of the South Pole the land surface is typically $1,000-3,000 \mathrm{ft}$. above sea-level and probably never below it; several ridges rise to a maximum of 7,000 ft. Twenty-five miles either side of the Pole the ice is very much thinner than at the Pole itself, and on the Ross Sea side remains thin, occasional crevassed areas being apparently on top of peaks covered by only $1,000 \mathrm{ft}$. of ice. The seismic results are generally confirmed by gravimetric data, but inaccuracies of the free air corrections weakens this support. American traverse parties endeavoured to minimize the effect of changing atmospheric pressures on elevations by leap-frogging. Considerable interest was shown in the experiences of the airborne seismic and glaciological unit under Dr. J. C. Cook (United States) operating from McMurdo Sound. Seismic soundings, gravity readings and glaciological studies were made at three stations on the plateau west of the Royal Society Range. At one of these stations the aircraft remained on the ground, while at the other stations the aircraft returned to base during observations. The seismic soundings were not very successful. Gravity deficiencies of more than $100 \mathrm{mgal}$. below McMurdo pendulum station were obtained, assuming ice to sea-level. A negative anomaly of similar magnitude is reported from the South Pole.

Dr. H. van Loon (South Africa) took the chair at the session on "Meteorology", which was opened by R. Taylor (United States) with an account of the work of Weather Central and the complex communication and reporting network which supplies information to Little America. Commander $J$. Mirabito (United States) recalled the great difficulties of operational forecasting in the Antarctic during 'Deepfreeze' I and II before the reporting network got into stride, when long-range flights were made on forecasts using data from McMurdo Sound supported by a few scattered ships. Air operations, however, have never been hampered by strong winds, and
Commander Mirabito could only recall one incident involving aircraft icing during polar flights. I. Kerr (New Zealand) pointed out that with the present, reporting network, Antarctic weather data are available to mid-latitude forecasters, but so far they have made little improvement in the effectiveness of New Zealand forecasting. Any improvement would be through a better knowledge of general atmospheric circulation and processes resulting from Antarctic studies. In common with other meteorologists in the southern hemisphere, he emphasized the large oceanic gaps in reporting centres, which only weather ships could fill. Forecasting of gales at a station where synoptic data were not available was discussed by Dr. J. Shear (United States). Changes in pressure were of little use, and though cloud sequences were classical and informative, Shear found that the most effective tool was a 'time-hodograph' of the wind vector at the $500-\mathrm{mb}$. level.

Soviet aerologists led by Dr. O. Krichek considered that the configuration of the Antarctic continent and particularly its northward extensions was responsible for six regions of stable high-pressure tongues. Reinforcement of these tongues blocks cyclones over the adjoining seas, and zones of stationary cyclones between these ridges occur in the Weddell Sea, off eastern Queen Maud Land, Mackenzie Sea, off Wilkes and George V Land, and in the Ross Sea. Ridges of the Antarctic anticyclones may connect with subtropical anticyclones, inhibiting zonal circulation, which is by no means exclusively typical in the southern hemisphere. Aerial reconnaissance for ice over the Davis Sea confirms that the cyclonic zones have a substantial effect on the position of the ice belt. At Mirny during the winter, inversions of up to $35^{\circ} \mathrm{C}$. were recorded and often persisted, though down-slope winds reached a velocity of $40 \mathrm{~m} . / \mathrm{sec}$.

Prof. H. Hoinkes (United States), who was chairman of the session on "Radiation", discussed the heat balance equation at Little America. He carefully measured or assessed the various factors: radiation balance, turbulent exchange, latent heat change, precipitation exchange and conduction from below. Latent heat, precipitation exchanges and conduction from below are not significant. Winds and temperatures measured at several levels up to a height of $17 \mathrm{~m}$. show that turbulent exchanges are rarely of much importance at Little America. Thus, radiation balance is the only important term in the equation and this was studied with a Link-Fuessner solarimeter, Schultze net radiometer and an Ang. ström pyrgeometer. The lowest outgoing radiation recorded was 0.08 langley/min., but only occasionally was 0.06 langley $/ \mathrm{min}$. exceeded. Inversion in the presence of clear skies would decrease this to 0.02 langley $/ \mathrm{min}$. Summer albedos were remarkably high. At the South Pole the mean of 100 readings was 0.89 (range, $0.845-0.943$ ); at Byrd Station $0 \cdot 88$, and at Little America 0.90 after fresh snow.

A unique and important part of the Soviet radiation programme, described by Dr. V. I. Shliakhov, was the measurement of the short-wave radiation balance at various altitudes. Special flights were made for this purpose. The great transparency of the Antarctic atmosphere undoubtedly accounts for the very low linear gradient of 0.0004 langley/min. per $100 \mathrm{~m}$. up to $4,500 \mathrm{~m}$. The figure for medium latitudes in Europe is $0.03-0.04$ langley/min. per $100 \mathrm{~m}$. The instrumental diversity in measurements of radiation made at Antaretic stations was very 
apparent in discussion. Shliakhov used a Yanishevsky balance meter and attempted to protect it from wind and snow damage by shielding it with a polyethylene cover $20 \mu$ thick. A minor parlour game was played of deriving the minimum possible surface temperature in Antarctic regions. Shliakhov gave $-80^{\circ} \mathrm{C} . \pm$ $2^{\circ}$ C., while Taylor preferred $-78^{\circ} \mathrm{C}$. The lowest surface temperature recorded at the South Pole station during 1957 was $-74^{\circ} \mathrm{C}$.

The chair for the session on "Oceanography" was taken by R. M. Cassie (New Zealand). The presence of the Soviet research ship $O b$ in Wellington during the symposium ensured a strong representation of Russian marine scientists. An account of the first two Antarctic cruises of $O b$ (1956 and 1957) was given by Prof. V. Kort. During these two cruises 329 oceanographic and 225 geological stations were occupied, mainly in the Indian sector of Antarctica. About 150 cores $2 \cdot 0-5 \cdot 5 \mathrm{~m}$. long have been taken by a gravitator tube, and five cores of $16 \mathrm{~m}$. have been taken by a piston corer. The present cruise is charged with similar investigations in the Pacific sector of Antarctic waters. From continuous echo soundings and cores, Dr. A. V. Jivago (U.S.S.R.) was able to discuss the types of bottom relief in the southern Indian Ocean and east Antarctic seas. Extremely complicated volcanic relief covers approximately two-thirds of the area explored. Besides the known volcanic chains extending from the Atlantic Ocean across the Crose plateau to the Kerguelen-Gauss range, big sub-surface volcanoes have been discovered to the west of Heard Island and north-west of the Prince Edward Islands. Their relative heights reach $3,000 \mathrm{~m}$. Vast areas consist of lava plains with stepping, hilly and block surfaces. The Antarctic Shelf, which represents the most complicated type of relief, was investigated in more detail. Its boundary is considerably deeper than other continents $(500 \mathrm{~m}$. or more), the surface is often rough and in some places devoid of covering sediment. Several morphological sub-types have been distinguished within the Shelf limits.

According to Dr. A. P. Andriashev (U.S.S.R.), who described the ichthyological investigations of $O b$, 1,100 specimens representing 75 species and 16 families have been caught. In the shallow water of the eastern Antarctic continent, trematoms and Gymnodraco acuticeps are the most abundant species, and some of these, especially $T$. bernacchi, may have some fishing importance to wintering-over parties. New types of chænichthyid and harpagiferid fishes were found among fishes caught by trawls at depths between 100 and $3,000 \mathrm{~m}$. Eight more species of the white-blooded chænichthyidae were added to the five already known. Qualitative investigations of the bottom and plankton invertebrates have shown the extremely low productivity of food forms (for fishes) of the bottom fauna, in comparison with the rich development of the pelagic crustaceans, substantiating Nybelin's hypothesis concerning the cause of partial transition of many bottom notothenioid fishes to pelagic feeding habits. The factors governing the character of bottom fauna of the shelf are the great depth of the boundary, complicated relief, extremely poor sorting of bottom sediments, and strong bottom currents which carry the subsiding detritus away to the ocean. Consequently, an extremely rich and varied fauna of sponges, colenterates, bryozoans, brachiopods, ascidians and an impoverished fauna of crustaceans and molluses are characteristic of the Shelf. One of the main differences between the Shelf faunas of Antarctica and that of other areas is that the polymixtous nature of the former makes it very difficult to ascertain the leading species.

Dr. R. W. Burling (New Zealand) exhibited a vertical section of isotherms south of New Zealand, in which tongues of cold water are present in positions suggesting the existence of a large horizontal eddy. Such eddies would have a great influence on mixing between various water masses in their predominantly eastward flow. The theoretical model of the Antarctic circumpolar current propounded by Hidaka and Tsuchiya, in fact, requires an occurrence of such eddies.

Dr. T. Hatherton (New Zealand) was chairman of the session on "Seismology". Epicentres within the Antarctic area were reported only by Scott Base (including tremors from Erebus) and Halley Bay, although stations along the coast of East Antarctica report a plenitude of seisms from the Indian Antarctic swell. Both d'Urville and particularly Scott Base reported remarkable changes in microseismic activity, very low in winter, very high in summer, presumably related to the effect of pack ice on the generation or transmission of microseismic energy. The successful operation of seismographs on floating ice (Halley Bay) and inland névé (South Pole and Byrd) was of considerable interest.

The chair for the meeting devoted to "Biology" was taken by Dr. R. A. Falla (New Zealand). Observations made on the Byrd traverse were summarized by Dr. D. Hale (United States). Eleven snow petrels and twelve skua gulls were sighted at distances more than 300 miles from the coast. A penguin track was discovered at $77 \frac{1}{2}^{\circ} \mathrm{S}$., $99^{\circ} \mathrm{W}$. at an altitude of $1,260 \mathrm{~m}$. The track was followed for more than a mile and traces of urine and fæces obtained. More than sixty specimens of lichens were collected; the entire collection with possibly two exceptions seems to be composed of species previously undescribed. Umbelicaria is noticeably absent and there is no Usnea sp., which is present all along the coast of Antarctica. Lecedia sp. and Buellia sp. predominate, as might be expected, and Alectoria sp. seems fairly widespread. In the Sentinel Mountains area individual nunataks, though fairly close in location, may have rather different floras. Flora affinities seem to be with the lichens of the west coast rather than with those of the Edsel Ford Mountains.

Dr. K. A. Brodsky (U.S.S.R.) has examined the mass development of phytoplankton in the cold waters near the continent, and along sections on the $90^{\circ}$ E. and $78^{\circ}$ E. meridians, with the northern boundary near $63^{\circ} \mathrm{S}$. Zooplankton was poor in waters rich with phytoplankton, but increased to the north. The biomass in the northern regions did not exceed $0.75 \mathrm{gm} . / \mathrm{m}^{3}$, whereas in the phytoplankton zone there was not less than $1 \mathrm{gm} . / \mathrm{m} .^{3}$, sometimes reaching more than $7 \mathrm{gm} . / \mathrm{m}^{3}$. In Antarctic waters the cold intermediate layer is not impoverished, but is somewhat richer in plankton than the superficial one. Brodsky considers that the term 'Sub-Antarctic', like 'Sub-Arctic', should be discarded for biogeographical purposes. $\mathrm{He}$ prefers a subdivision into 'Antarctic' (northern boundary between $60^{\circ} \mathrm{S}$. and $52^{\circ} \mathrm{S}$. for different areas), 'Notal' (northern boundary between $50^{\circ} \mathrm{S}$. and $40^{\circ} \mathrm{S}$.) and 'Tropical'. Brodsky proposes using the composition and distribution of the Celanoid to compare the biogeographical regions of both hemispheres. Data on bird-banding, sealbranding and other studies were exchanged, and 
Pewe reported the discovery of 81 carcasses of crabeater seals at altitudes of $1,000-2,000 \mathrm{ft}$. in the foothills of the Prince Albert Mountains.

Dr. F. Jacka (Australia) occupied the chair at the session on "Aurora". Interest centred mainly on radio echoes and the problem of relating them to visually observed auroras. At Invercargill, all-sky camera and very high-frequency radio-echo equipment have been run continuously. M. Gadsden's (New Zealand) analysis of six months results showed that the probability of aurora being present at the same time as radio echoes increases with increase in local $K$-index, suggesting that there is no intimate connexion between visual aurora and radio echoes. Radio echoes show a broad maximum in oceurrence at local midnight ( 35 per cent) and a minimum shortly before local noon ( 3 per cent), whereas no significant diurnal variation has been detected in the oceurrence of visual auroras. The echoing region heights average $110 \mathrm{~km}$. and, with the radar looking south, radial velocities are generally inward (that is, northward) before local midnight and outward (southward) after, with an average north/south radial velocity of $400 \mathrm{~m}$./sec. K. Bullough's (France) measurements at d'Urville (geomagnetic latitude $75 \cdot 5^{\circ}$ S.) showed that diurnal distribution of echoes displays a very sharp peak in the evening in winter with more even occurrence throughout the day in summer. The echoes occur almost entirely to the north during the winter months, with a marked increase in activity to the south in summer. Skip echoes are believed to have been observed on three occasions. Analysis of the d'Urville results is not yet sufficiently advanced to permit correlation with visual activity. All stations reported little success with spectrographs. Many observers commented upon poor design and engineering features which restricted the operation of their instruments. Little discussion was possible on visual auroral observations at Antarctic stations as the results have not yet been reduced.

The closing session was devoted to "Future Research in the Antarctic", with Dr. G. de Q. Robin (Great Britain) in the chair. Seven speakers discussed future work in their respective fields. Dr. F. Jacka, dealing with the physies of the upper atmosphere, requested more studies of 'whistlers' and the 'dawn chorus', which have hitherto been almost entirely neglected. He also suggested a better geographical distribution of cosmic ray stations, which are at present concentrated around the coast of the AfricanAustralian quadrants. Spectrographic studies of the aurora have been less successful than expected. Simpler instruments with more limited objectives might be preferable for future work. B. Imbert, speaking on ice cover and glacial relief, reviewed the achievements of the past year in seismic sounding, and came to the conclusion that tractor trains with close air support, using mechanized drilling techniques to place a small charge as deep as possible below the surface, form the most desirable unit. The high plateau of east Antarctica offers the severest challenge. There was some discussion on the use of radio waves for soundings of the depth of ice, but in the absence of confirmed experiments using these techniques, normal seismic methods must continue to be used. The use of the triangular traverse was urged, as being more informative and easier to support. Prof. Shoumsky, dealing with general glaciological problems, outlined possible future Russian traverses, but urged that attention be paid to general ice regime, heat- and mass-balance as well as to form and dimensions. The morphology of the huge ice streams of the continent is an especially desirable study, but one of considerable difficulty because of the broken and crevassed nature of the boundaries. With regard to meteorology, R. Taylor considered that it is now possible to obtain a reasonable representation of the mean circulation over the Antarctic, but a comprehensive picture of southern hemisphere circulation is impossible in the foreseeable future, because of the lack of information over the southern oceans. $\mathrm{He}$ endorsed the use of weather ships, as did many other speakers at the symposium. As a by-product of Antarctic work, he predicted considerable improvement in many instruments. Meteorological flights have not been used as often or extensively as they should. Prof. V. G. Kort summarized comprehensively the needs of oceanographic research over the next ten years. In particular, he pleaded for much more concentrated work in zones of convergence and divergence, and in coastal waters an extension of hydrological work at coastal stations, where remarkably few oceanographic studies are done, and comprehensive studies of the pack ice by monthly flights from coastal bases. Actinometric studies have been successfully carried out this season on $O b$ and offer considerable scope in the future.

Dr. R. A. Falla considered that biological studies in the Antarctic had benefited during the International Geophysical Year although they were not planned explicitly, except in the case of the larger vertebrates, where banding and branding studies had been successfully carried out. Amateur observers could do valuable preliminary studies in biological fields, which could be examined to see where professional studies were required. He cited as an outstanding example the collection of lichens from the Marie Byrd Land mountains by the Byrd traverse party. Intensification of taxonomic, ecological and physiological studies was required. Biological research suffers from inadequate national and international organization, and this must be remedied before Antarctic biological research can achieve the same effectiveness as that in the physical sciences. Falla ended with a plea for the greater participation by mature scientists in expeditions, thus emphasizing a weakness in most British Antaretic teams, which rely unduly on the efforts of young graduates.

Dr. T. Hatherton, speaking on the future of crustal geophysics, emphasized the need for precise levelling to the main inland bases. Antarctic seismic activity appears to be present only in the areas of the Ross and Weddell Seas, and determinations of epicentres require at least two stations. He suggested that such dual stations (less than $100 \mathrm{~km}$. apart) might be useful also for gradient and movement investigations in the upper atmosphere, though Jacka preferred dispersion of the stations in ionosphere studies. Seismic and magnetometer work at sea in the areas of most structural interest were recommended. Geology needs no specific recommendations but should be carried out wherever exposures are available. Dr. Robin closed the meeting by pointing out that the best contribution that scientists attending the symposium could make to future research was to work up their results as soon as possible, before new interests and opportunities arise to distract them from completing their Antarctic work by its final publication.

T. HATHERTON 